\title{
The microbiological quality of food in hospitals kitchen in Khartoum State, Sudan
}

\author{
Hilwa Hamid Bajin Salam 1,*, Ekram Adam Eldoom ${ }^{2}$, Fatima Fadul Ali ${ }^{2}$ and Abeer Magthop Mohammed ${ }^{2}$ \\ ${ }^{1}$ Ministry of Health, Department of Nutrition, Khartoum, Sudan. \\ ${ }^{2}$ Khartoum North, Faculty of Public Health, Alzaiem Alazhari University, Sudan.
}

Magna Scientia Advanced Biology and Pharmacy, 2021, 03(01), 049-057

Publication history: Received on 05 July 2021; revised on 18 August 2021; accepted on 20 August 2021

Article DOI: https://doi.org/10.30574/msabp.2021.3.1.0033

\begin{abstract}
An interventional research was conducted in the kitchens of Khartoum state hospitals 2021 on the impact of microbial quality in (12) hospital. Samples taken from meals, hands, environment, surfaces, equipment, and utensils before and after interventions and measuring results. Questionnaires were filled out with interview with nutrition supervisor about kitchens. The data was statistically analyzed by using the Statistic Package for Social Sciences (SPSS) program version 25; the Paired Samples T Test and Chi-Square Test was used and there is an improvement at the level of indication 0.000 at the level (0.05). The results showed that the lack of quality of kitchens in buildings, equipment, utensils, hand facilities and no periodic inspection for raw materials. The study concluded that taken samples has an effective impact on microbial quality. The study recommended that the ministry of health and hospitals to commitment to take samples periodically.
\end{abstract}

Keywords: Bacteria; Examination; Impact; Common

\section{Introduction}

Kitchens should be part of a structured and organized department that provides nutritional assistance by preparing high quality meals with standards of food safety [1].

The measurement of the safety of foods has relied on evaluation of the microbiological quality of foods [2, 3].

Bacterial counts in prepared food or water is a key factor in assessing the quality and safety of food, and can reveal the hygiene level adopted by food handlers in the course of preparation of such foods [4].

In a recent review, E. coli, Shigella, Salmonella and Campylobacter spp. are the most commonly reported causes of gastrointestinal disease and all have been associated with foodborne disease $[5,6]$.

However, in developing countries, monitoring the microbial safety of foods is not routine practiced, due to a lack of infrastructure and effective food safety regulations and standards [7]. Hence, there is a great wanted for taken samples.

This study is aimed to determine the microbial contamination of food in the hospital kitchens pre and post intervention.

\footnotetext{
${ }^{*}$ Corresponding author: Hilwa Hamid Bajin Salam

Ministry of Health, Department of Nutrition, Khartoum, Sudan.

Copyright (C) 2021 Author(s) retain the copyright of this article. This article is published under the terms of the Creative Commons Attribution Liscense 4.0.
} 


\section{Material and methods}

The study area is hospital kitchens in Khartoum state that have (51) governmental hospital, only (35) hospital have kitchens that prepare food for patients and health workers through food handlers. The kitchen operates full-time and serves food for breakfast, lunch and dinner (breakfast selected for sample). Only twelve (12) hospitals selected.

Listing all hospital kitchens in Khartoum state hospitals that obtained from the ministry of health. Then stratified according to their localities Khartoum, Omdurman and Bahri. A stratified random sampling was selected hospitals. Twelve (12) hospitals participated in the study, 41.7\% (5) Khartoum locality (Ibn Senna, Dermal, Abdalalfadual Almaz, AL academy, Turkish), 33.3\% (4) Omdurman locality (Mohamed Alamin Hamid, Omdurman teaching, Aboanga, Abosed), and 25\% (3) Bahri locality (Bahri teaching, Alshohada and Omdwaban).The data was collected using different methods. Firstly, interview, and microbiological examination that designed to collect primary data from the selected sample and then secondary data was collected using available published information in books, journals, reports, internet and studies in different sources. Face-to-face interviews with supervisors in the hospital kitchens selected in Khartoum state. The interviews were in this study to identify awareness of the interviewees toward food hygiene practices. The interviews take place within the food premises and each interview approximately 10 -to15 minute. The questionnaire include (31) questions such as general information about the food premises such as the number of bed, estimated number of meals distributed, the number of food services staff, the Hazard Analysis Critical Control Point (HACCP) system implementation status.

\section{Microbiological Examination}

It is frequently necessary to conduct a microbiological examination of food to determine its quality. This may be necessary to estimate enumeration of Escherichia coli (E. coli), total aerobic mesophilic bacteria and total plate counts (APC) in food [8].

Food samples was prepared, cultured in their respective media and incubated. The microorganisms is identify and their counts and compare to standard values of microbiological counts $[9,10]$.

The hands of food handlers, equipment, utensils, environment and surfaces was swabbed using sterile cotton smears moistened with sterile normal saline solution. The samples were transported as soon as possible to the laboratory using an insulated icebox containing an ice pack. The sample was culture in suitable media.

A plate was incubated under aerobic condition at $37^{\circ} \mathrm{C}$ for $24-48 \mathrm{~h}$. After the incubation, isolated species is identifying using Gram strain, colony morphology and appropriate biochemical tests [11].

\section{Ethical Considerations}

The research approval was obtained from the university and was obtained from the Khartoum state ministry of health research department that have authorizing data collection from hospitals.

The interviewee was asked to participate in the study voluntarily. The interviewees have right to withdraw at any time without any deprivation from research benefit. Confidentiality was guaranteed by not indicating interviewee names in data collection tool. Each participant was informed about the objective of the study and privacy during interview was ensured. The interview was done in their rest time without any interruption to their work.

\section{Results and discussion}

\subsection{1 /The-building conditions of the hospitals kitchens}

Table 1 Hospitals kitchen characteristic $(n=12)$

\begin{tabular}{|l|c|}
\hline Statement & No \\
\hline Beds & 269 \\
\hline Meals /day & 1813 \\
\hline Staff & 190 \\
\hline
\end{tabular}


The numbers of beds (269), and meals distributed daily (1813) meals and these meals throughout (41) Dietitians, (54) Nutrition counseling, (30) cooks, (54) services and (11) workers.

Table 2 The hospital kitchens $(\mathrm{n}=12)$

\begin{tabular}{|c|c|c|c|c|}
\hline \multirow{2}{*}{ Statement } & \multicolumn{2}{|c|}{ Yes } & \multicolumn{2}{|c|}{ No } \\
\hline & Frequency & $\%$ & Frequency & $\%$ \\
\hline Adequate ventilation & 6 & 50.0 & 6 & 50.0 \\
\hline Adequate lights & 8 & 66.7 & 4 & 33.3 \\
\hline Washing hand & 2 & 16.7 & 12 & 83.3 \\
\hline Room change & 3 & 25.0 & 9 & 75.0 \\
\hline Food storage procedure & 3 & 25.0 & 9 & 75.5 \\
\hline Any procedure for personal hygiene & 3 & 25.0 & 9 & 75.0 \\
\hline HACCP system & 0 & 0.0 & 12 & 100.0 \\
\hline Food hygiene operating procedure & 0 & 0.0 & 12 & 100.0 \\
\hline Continuing education courses on HACCP & 0 & 0.0 & 12 & 100.0 \\
\hline Continuing education courses on food hygiene & 0 & 0.0 & 12 & 100.0 \\
\hline Use critical control point's tree & 0 & 0.0 & 12 & 100.0 \\
\hline Clean and disinfect surfaces and equipment & 8 & 66.7 & 4 & 33.3 \\
\hline Check foods temperature & 1 & 8.3 & 11 & 91.7 \\
\hline Inspection of raw materials & 5 & 41.7 & 7 & 58.3 \\
\hline Microbiological testing of the kitchen & 0 & 0.0 & 12 & 100.0 \\
\hline Microbiological testing of the food & 0 & 0.0 & 12 & 100.0 \\
\hline Microbiological testing of the surfaces & 0 & 0.0 & 12 & 100.0 \\
\hline Microbiological testing of the equipment & 0 & 0.0 & 12 & 100.0 \\
\hline Microbiological testing of the utensils & 0 & 0.0 & 12 & 100.0 \\
\hline All workers have medical certificate & 10 & 83.3 & 2 & 16.7 \\
\hline Every six months & 9 & 75.0 & 3 & 25.0 \\
\hline Every year & 1 & 8.3 & 11 & 91.7 \\
\hline Other (specify) & 0 & 0.0 & 0.0 & 0.0 \\
\hline Release any food handlers if ill & 12 & 100.0 & 0 & 0.0 \\
\hline Diarrhea & 3 & 25.0 & 0 & 0 \\
\hline Fever & 5 & 41.7 & 0 & 0 \\
\hline Other (specify) & 4 & 33.3 & 0 & 0 \\
\hline Very poor condition & 5 & 41.7 & 0 & 0 \\
\hline Poor condition & 3 & 25.0 & 0 & 0 \\
\hline Average condition & 2 & 16.7 & 0 & 0 \\
\hline Good condition & 1 & 8.3 & 0 & 0 \\
\hline Very good condition & 1 & 8.3 & 0 & 0 \\
\hline
\end{tabular}


Data presented in Table (2) shows that an adequate ventilation in 6(50\%), an adequate lights 8(66.7\%), only two hospitals (16.7\%) had washing hand facility and three hospitals had food storage and personal hygiene procedure (25.0\%) These results agree with the study that conducted in Kenya by Nyamari, 2013, which aimed to identify gaps with regard to status of the hospital kitchen, status and storage of equipment, some aspects of personal hygiene and sanitation and vector control [12].

\subsection{Microbiological Analysis}

Table 3 The bacteria count in Environment and Surfaces

\begin{tabular}{|c|c|c|c|c|c|c|}
\hline \multirow{2}{*}{ Hospitals } & \multirow{2}{*}{ No of sample } & \multicolumn{2}{|c|}{ Environment } & \multirow{2}{*}{ No of sample } & \multicolumn{2}{c|}{ Surfaces } \\
\cline { 7 - 7 } \cline { 6 - 7 } & & Before & After & & Before & After \\
\hline A & 1 & $>300$ & 200 & 1 & $>300$ & 80 \\
\hline B & 1 & $>300$ & 53 & 1 & $>300$ & $>300$ \\
\hline C & 1 & $>300$ & 165 & 1 & $>300$ & $>300$ \\
\hline D & 1 & $>300$ & 225 & 1 & $>300$ & $>300$ \\
\hline E & 1 & $>300$ & 74 & 1 & $>300$ & $>300$ \\
\hline F & 1 & $>300$ & 165 & 1 & $>300$ & $>300$ \\
\hline G & 1 & $>300$ & 68 & 1 & $>300$ & 39 \\
\hline H & 1 & $>300$ & 74 & 1 & $>300$ & $>300$ \\
\hline I & 1 & $>300$ & 70 & 1 & $<30$ & 110 \\
\hline J & 1 & $>300$ & $>300$ & 1 & $>300$ & 163 \\
\hline K & 1 & $>300$ & $>300$ & 1 & $>300$ & 0 \\
\hline L & 1 & $>300$ & 220 & 1 & $>300$ & 150 \\
\hline
\end{tabular}

All $12(100 \%)$ none of the hospitals adopted any educational courses on HACCP trainings or food hygiene for food handlers and not used critical control point's tree. This finding agree with the study that conducted in Kenya by Wandolo, 2016 which aimed to carry out a comparative study of training on food safety and hygiene in TVET and University Hospitality schools and their impact on hygiene practices in the hospitality industry[13]. The HACCP prerequisites were not used in most of the institutions. In several studies, food service workers that received training had better hygiene scores and safe food handling practices than those that did not receive training. Eight (66.7 \%) of the hospitals had clean and disinfect surfaces and equipment and four (33.3\%) had not clean and disinfect. only one hospitals kitchen had check foods temperature $(8.3 \%)$ that done through observation. Foods were not to be in the danger zone (between $5^{\circ \mathrm{c}}$ and $60^{\circ} \mathrm{c}$ ) longer than necessary. If food is not chilled or frozen during storage; and heated to temperatures between 70 and 80 before consumption, then there are high chances of growth and subsequent ingestion of pathogens and for this reason needed to check foods temperature. Five (41.7 \%) of the hospitals had inspection of raw materials and seven (58.3\%) had not inspection and this indicated to some hospitals were not aware about used it in their kitchens. Only one hospitals kitchen had check foods temperature (8.3\%). The routine inspections wanted to prevent foodborne illness by ensuring safe food handling and preparation. This study finding that the hospital kitchens were not inspected often. (100\%) none of the hospitals had any microbiological testing for their kitchens Microbiological testing is very important to reduce foodborne illness and the most studies suggested taking samples from kitchens to microbial quality testing. Across sectional descriptive study conducted in Sudan by Omer, 2017 to determine the status of food safety and hygiene in 16 hospitals the results confirm that the microbial tasting was vital issues in hospitals kitchens [14]. The table shows that 10 (83.3\%) of the hospitals kitchens had medical certificate and two $(16.7 \%)$ had no certificate. Nine $(75.0 \%)$ of the hospitals check certificate every six months and one $(8.3 \%)$ every year. The data presented that all (100\%) of the hospitals release food handlers when ill. The five (41.7\%) fever, four $(33.3 \%)$ any other symptoms and three $(25.0 \%)$ diarrhea. Five $(41.7 \%)$ of the hospitals kitchen had very poor food safety practice and one (25.0\%) had poor practice in kitchens. 
Table 4 The bacteria count in Food Handlers and Meals

\begin{tabular}{|c|c|c|c|c|c|c|}
\hline \multirow[b]{2}{*}{ Hospitals } & \multirow[b]{2}{*}{ No of sample } & \multicolumn{2}{|c|}{ Food Handlers } & \multirow[b]{2}{*}{ No of sample } & \multicolumn{2}{|c|}{ Meals } \\
\hline & & Before & After & & $\begin{array}{c}\text { Befor } \\
\text { e }\end{array}$ & After \\
\hline A & $4 / 4$ & $>300$ & 100 & $3 / 3$ & $>300$ & 77 \\
\hline B & $2 / 2$ & $>300$ & 165 & $3 / 2$ & $>300$ & 172 \\
\hline $\mathrm{C}$ & $2 / 2$ & $>300$ & 250 & $1 / 1$ & $>300$ & 62 \\
\hline D & $2 / 2$ & $>300$ & 297 & $3 / 2$ & $>300$ & $>300$ \\
\hline $\mathrm{E}$ & $4 / 4$ & $>300$ & $>300$ & $2 / 2$ & $>300$ & 80 \\
\hline $\mathrm{F}$ & $10 / 10$ & $>300$ & $>300$ & $3 / 1$ & $>300$ & 165 \\
\hline $\mathrm{G}$ & $8 / 8$ & $>300$ & $>300$ & $2 / 2$ & $<30$ & $>300$ \\
\hline $\mathrm{H}$ & $4 / 4$ & $>300$ & 183 & $4 / 2$ & $>300$ & $<30$ \\
\hline I & $3 / 3$ & $<30$ & 233 & $2 / 4$ & $>300$ & 194 \\
\hline $\mathrm{J}$ & $11 / 11$ & $>300$ & 165 & $5 / 3$ & $>300$ & $>300$ \\
\hline $\mathrm{K}$ & $3 / 3$ & $>300$ & 0 & $5 / 4$ & 39 & 0 \\
\hline $\mathrm{L}$ & $3 / 3$ & $>300$ & 0 & $4 / 2$ & $>300$ & 0 \\
\hline Total & $56 / 56$ & & & $34 / 28$ & & \\
\hline
\end{tabular}

Table 5 The bacteria count in Equipment

\begin{tabular}{|c|c|c|c|c|c|c|c|c|c|}
\hline \multirow{2}{*}{ Hospitals } & \multirow{2}{*}{$\begin{array}{l}\text { No of } \\
\text { sample }\end{array}$} & \multicolumn{2}{|c|}{ Refrigerator } & \multirow{2}{*}{$\begin{array}{l}\text { No of } \\
\text { sample }\end{array}$} & \multicolumn{2}{|c|}{$\begin{array}{l}\text { Refrigerator } \\
\text { home }\end{array}$} & \multirow{2}{*}{$\begin{array}{l}\text { No of } \\
\text { sample }\end{array}$} & \multicolumn{2}{|l|}{ Cooker } \\
\hline & & Before & After & & Before & After & & Before & After \\
\hline $\mathrm{A}$ & 1 & $>300$ & 150 & 1 & $>300$ & 250 & 1 & $>300$ & 124 \\
\hline B & 1 & $<30$ & $>300$ & 1 & $>300$ & $>300$ & 1 & $>300$ & $>300$ \\
\hline $\mathrm{C}$ & 1 & $>300$ & $>300$ & 1 & $>300$ & $>300$ & 1 & $>300$ & $>300$ \\
\hline $\mathrm{D}$ & 1 & $>300$ & $>300$ & 1 & $>300$ & $>300$ & 1 & $>300$ & $>300$ \\
\hline $\mathrm{E}$ & 1 & $>300$ & $>300$ & 1 & $>300$ & $>300$ & 1 & $>300$ & $>300$ \\
\hline $\mathrm{F}$ & 1 & $>300$ & $>300$ & 1 & $>300$ & 123 & 1 & $>300$ & $>300$ \\
\hline G & 1 & $>300$ & $>300$ & 1 & $>300$ & $>300$ & 1 & $>300$ & $>300$ \\
\hline $\mathrm{H}$ & 1 & $>300$ & $>300$ & 1 & $>300$ & $>300$ & 1 & $>300$ & 120 \\
\hline I & 1 & $>300$ & 225 & 1 & $>300$ & $>300$ & 1 & $>300$ & $>300$ \\
\hline $\mathrm{J}$ & 1 & 0 & 0 & 1 & 0 & 0 & 1 & $>300$ & $>300$ \\
\hline $\mathrm{K}$ & 1 & $>300$ & 0 & 1 & $>300$ & 0 & 1 & $>300$ & 0 \\
\hline $\mathrm{L}$ & 1 & $>300$ & 124 & 1 & $>300$ & 134 & 1 & $>300$ & $>300$ \\
\hline
\end{tabular}


Table 6 The bacteria count in Utensils

\begin{tabular}{|c|c|c|c|c|c|c|c|c|c|c|c|c|c|c|c|c|c|}
\hline \multirow{2}{*}{ Hospitals } & \multirow{2}{*}{$\begin{array}{c}\text { No of } \\
\text { sample }\end{array}$} & \multicolumn{2}{|c|}{ Bola } & \multicolumn{2}{|c|}{ Cutting board } & \multicolumn{2}{|c|}{ Spoons } & \multicolumn{2}{|c|}{ Plates } & \multicolumn{2}{|c|}{ Knives } & \multicolumn{2}{|c|}{ Dollop } & \multicolumn{2}{|c|}{$\begin{array}{c}\text { Distribution } \\
\text { container }\end{array}$} & \multicolumn{2}{|c|}{ Package } \\
\hline & & Before & After & Before & After & Before & After & Before & After & Before & After & Before & After & Before & After & Before & After \\
\hline A & 1 & $>300$ & 158 & $>300$ & 175 & $>300$ & 185 & $>300$ & 132 & $>300$ & 12 & $>300$ & 150 & $>300$ & 145 & $>300$ & 98 \\
\hline B & 1 & $>300$ & $>300$ & $>300$ & $>300$ & $>300$ & $>300$ & $>300$ & 242 & $>300$ & $>300$ & $>300$ & $>300$ & $>300$ & $<30$ & $>300$ & 259 \\
\hline $\mathrm{C}$ & 1 & $>300$ & $>300$ & $>300$ & $>300$ & $>300$ & $<30$ & $>300$ & $>300$ & $>300$ & 85 & $>300$ & $>300$ & $>300$ & $>300$ & $>300$ & $>300$ \\
\hline $\mathrm{D}$ & 1 & $>300$ & $>300$ & $>300$ & $>300$ & $>300$ & $>300$ & $>300$ & $>300$ & $>300$ & $>300$ & $>300$ & 75 & $>300$ & $>300$ & $>300$ & $>300$ \\
\hline $\mathrm{E}$ & 1 & $>300$ & $<30$ & $>300$ & $>300$ & $>300$ & $>300$ & $>300$ & $>300$ & $>300$ & $>300$ & $>300$ & $>300$ & $>300$ & $>300$ & $>300$ & $>300$ \\
\hline $\mathrm{F}$ & 1 & $>300$ & $>300$ & $>300$ & $>300$ & $>300$ & $>300$ & $>300$ & $>300$ & $>300$ & 237 & $>300$ & $>300$ & $>300$ & $>300$ & $>300$ & $>300$ \\
\hline G & 1 & $>300$ & $>300$ & $>300$ & $>300$ & $>300$ & $>300$ & $>300$ & $>300$ & $>300$ & $>300$ & $>300$ & $>300$ & $>300$ & $>300$ & $>300$ & $>300$ \\
\hline $\mathrm{H}$ & 1 & $>300$ & 120 & $>300$ & 68 & $>300$ & 230 & $>300$ & $>300$ & $>300$ & 165 & $>300$ & $>300$ & $>300$ & $>300$ & $>300$ & 182 \\
\hline I & 1 & $>300$ & $>300$ & 168 & $<30$ & $>300$ & 240 & $>300$ & $>300$ & $>300$ & $<30$ & $>300$ & $>300$ & $>300$ & $<30$ & $>300$ & $<30$ \\
\hline $\mathrm{J}$ & 1 & $>300$ & $>300$ & $>300$ & $>300$ & $>300$ & $>300$ & $>300$ & $>300$ & $>300$ & 183 & $>300$ & $>300$ & $>300$ & 109 & $>300$ & 0 \\
\hline $\mathrm{K}$ & 1 & $>300$ & 0 & $>300$ & 180 & 172 & 0 & 151 & 32 & 89 & $<30$ & $>300$ & 0 & $>300$ & 89 & $>300$ & 0 \\
\hline $\mathrm{L}$ & 1 & $>300$ & $>300$ & $>300$ & 120 & $>300$ & 230 & $>300$ & 290 & $>300$ & 75 & $>300$ & 150 & $>300$ & 0 & $>300$ & 28 \\
\hline
\end{tabular}

Table 7 The most commonly bacteria in food handlers and meals

\begin{tabular}{|c|c|c|c|c|c|c|c|c|c|c|c|c|c|c|c|c|}
\hline \multirow{2}{*}{ Sample } & \multicolumn{2}{|c|}{ Pseudomonas } & \multicolumn{2}{|c|}{ Campylobacter } & \multicolumn{2}{|c|}{ Staphylococcus } & \multicolumn{2}{|c|}{ Salmonella } & \multicolumn{2}{|c|}{ Kleibsella } & \multicolumn{2}{|c|}{ Proteus } & \multicolumn{2}{|c|}{ Enteriobacteria } & \multicolumn{2}{|c|}{ Fungi } \\
\hline & before & after & Before & after & before & after & before & after & before & after & before & after & before & after & before & after \\
\hline Meals & 9 & 0 & 0 & 0 & 5 & 1 & 8 & 1 & 5 & 3 & 8 & 8 & 0 & 2 & 0 & 0 \\
\hline Food Handlers & 8 & 3 & 0 & 0 & 6 & 3 & 9 & 1 & 7 & 6 & 7 & 7 & 0 & 4 & 0 & 0 \\
\hline Total & 17 & 3 & 0 & 0 & 11 & 4 & 17 & 2 & 12 & 9 & 15 & 15 & 0 & 6 & 0 & 0 \\
\hline
\end{tabular}


Table 8 The most commonly bacteria in environment and surfaces

\begin{tabular}{|c|c|c|c|c|c|c|c|c|c|c|c|c|c|c|c|c|}
\hline \multirow{2}{*}{ Sample } & \multicolumn{2}{|c|}{ Pseudomonas } & \multicolumn{2}{|c|}{ Camplybacteria } & \multicolumn{2}{|c|}{ Staphylococcus } & \multicolumn{2}{|c|}{ Salmonella } & \multicolumn{2}{|c|}{ Kleibsella } & \multicolumn{2}{|c|}{ Proteus } & \multicolumn{2}{|c|}{ Enteriobacteria } & \multicolumn{2}{|c|}{ Fungi } \\
\hline & before & after & before & after & before & after & before & after & before & after & before & after & before & after & before & after \\
\hline Environment & 11 & 2 & 0 & 0 & 7 & 7 & 9 & 4 & 5 & 4 & 0 & 3 & 0 & 4 & 12 & 7 \\
\hline Surfaces & 9 & 2 & 0 & 0 & 4 & 0 & 5 & 1 & 1 & 2 & 6 & 8 & 1 & 3 & 0 & 0 \\
\hline Total & 20 & 4 & 0 & 0 & 11 & 7 & 14 & 5 & 6 & 6 & 6 & 11 & 1 & 7 & 12 & 7 \\
\hline
\end{tabular}

Table 9 The most commonly bacteria in equipment

\begin{tabular}{|c|c|c|c|c|c|c|c|c|c|c|c|c|c|c|c|c|}
\hline \multirow[t]{2}{*}{ Sample } & \multicolumn{2}{|c|}{ Pseudomonas } & \multicolumn{2}{|c|}{ Camplybacteria } & \multicolumn{2}{|c|}{ Staphylococcus } & \multicolumn{2}{|c|}{ Salmonella } & \multicolumn{2}{|c|}{ Kleibsella } & \multicolumn{2}{|c|}{ Proteus } & \multicolumn{2}{|c|}{ Enteriobacteria } & \multicolumn{2}{|c|}{ Fungi } \\
\hline & before & after & Before & after & before & after & before & after & before & after & before & after & before & after & before & after \\
\hline Refrigerator & 8 & 2 & 0 & 0 & 3 & 2 & 7 & 0 & 2 & 1 & 5 & 8 & 1 & 4 & 7 & 0 \\
\hline Refrigerator home & 8 & 2 & 0 & 0 & 1 & 2 & 4 & 0 & 3 & 0 & 7 & 7 & 0 & 1 & 0 & 0 \\
\hline Cooker & 11 & 1 & 1 & 0 & 5 & 3 & 6 & 0 & 0 & 1 & 5 & 8 & 0 & 2 & 0 & 0 \\
\hline Total & 27 & 5 & 1 & 0 & 9 & 7 & 17 & 0 & 5 & 2 & 17 & 23 & 1 & 7 & 7 & 0 \\
\hline
\end{tabular}

Table 10 The most commonly bacteria in utensils

\begin{tabular}{|c|c|c|c|c|c|c|c|c|c|c|c|c|c|c|c|c|}
\hline \multirow{2}{*}{ Sample } & \multicolumn{2}{|c|}{ Pseudomanus } & \multicolumn{2}{|c|}{ Camplybacteria } & \multicolumn{2}{|c|}{ Staphylococcus } & \multicolumn{2}{|c|}{ Salmonella } & \multicolumn{2}{|c|}{ Kleibsella } & \multicolumn{2}{|c|}{ Proteus } & \multicolumn{2}{|c|}{ Enteriobacteria } & \multicolumn{2}{|c|}{ Fungi } \\
\hline & before & after & before & after & before & after & before & after & before & after & before & after & before & after & before & after \\
\hline Bola & 8 & 1 & 0 & 0 & 5 & 2 & 2 & 0 & 2 & 1 & 5 & 7 & 0 & 3 & 0 & 0 \\
\hline Cutting board & 8 & 0 & 0 & 1 & 5 & 2 & 5 & 0 & 3 & 2 & 5 & 6 & 0 & 5 & 0 & 0 \\
\hline Spoons & 9 & 1 & 0 & 0 & 4 & 0 & 4 & 1 & 2 & 2 & 8 & 7 & 0 & 3 & 0 & 0 \\
\hline Plates & 10 & 0 & 0 & 0 & 5 & 1 & 7 & 1 & 2 & 2 & 6 & 6 & 0 & 5 & 0 & 0 \\
\hline Knives & 8 & 0 & 0 & 0 & 5 & 1 & 6 & 0 & 3 & 5 & 7 & 8 & 0 & 4 & 0 & 0 \\
\hline Distribution container & 9 & 2 & 0 & 1 & 4 & 3 & 6 & 0 & 2 & 3 & 4 & 7 & 0 & 0 & 0 & 0 \\
\hline Dollop & 9 & 0 & 0 & 0 & 4 & 1 & 6 & 1 & 3 & 2 & 5 & 7 & 0 & 3 & 0 & 0 \\
\hline Total & 61 & 4 & 0 & 2 & 32 & 10 & 36 & 3 & 17 & 17 & 40 & 48 & 0 & 23 & 0 & 0 \\
\hline
\end{tabular}


The APC involved 264 samples that taken from 12 hospitals kitchens before and after intervention the environment (12-12), surfaces (12-12), utensils (96-96), equipment (36-36), food handlers (56-56) and meals (34-28). Six (50\%) of the hospitals kitchens had improvements in surfaces after intervention. Nine (75\%) of the hospitals kitchens had improvement in food handlers and meals after intervention. Only five (42\%) of the hospitals kitchens had improvement in refrigerator after intervention and there were no change in cooker.

There were improvement in hospitals kitchens A, E, H, and k in bola, A, H, I, K and L in cutting board, A, C, H, I, K and L in spoons, A, B, K and L plates, A, C, F, H, I, J, K and L in knives, A, D, K and L, A, B, I, K, and L in distribution container and A, B, H, I, J, K and L in package after intervention. The most pathogenic bacteria were found Pseudomonas.spp, Staphylococcus, Proteus.spp, Klebsiella.spp, Enterobacteria.spp Salmonella, Camplybacteria.spp and Fungi.

Proteus.spp and Enterobacteria.spp were high level in utensils and preventive from germs through wash hand and disinfected after toilet. In our study only two hospitals had washing hand facility. To designated places for handwashing with soap and water in or near the latrine and food preparation and cooking areas. This can help new practices to become part of the daily routine. Studies have shown that compliance of handwashing is higher when soap and water is immediately available.

The bacteriological quality of meals, food handlers, environment, surfaces, utensils and equipment improved after training intervention.

These results agree with the study that conducted in the Clinical Centre Niš, Serbia, 2013 to evaluate the effects of food hygiene training of food handlers on sanitary-hygienic conditions in hospital kitchens, based on microbiological analysis of smears taken in hospital kitchens. 1,076 smears in the central kitchen and 4,025 smears in distributive kitchens were taken from hands and work clothes, work surfaces, equipment, and kitchen utensils and microbiological analysis of smears. The results confirmed that food hygiene training improved hygiene and is an important component for the prevention of nosocomial infection [15].

\section{Conclusion}

The finding of this study indicated to improve the microbiological quality in hospitals kitchens to reduce the foodborne diseases before and after training intervention in Khartoum state of the hospitals kitchens. The result of the building condition had very poor food safety practice and kitchens hygiene. Not had adequate lighting and ventilation, only two hospitals had washing hand facility and three hospitals had food storage and personal hygiene procedure. Not all the hospitals adopted any educational courses on prerequisites of food safety and HACCP training before and addition not used critical control point's tree. Eight of the hospitals had clean and disinfect surfaces and equipment and four not had. Only one hospitals kitchen had check foods temperature. Only five of the hospitals had inspection of raw materials and seven not had inspection. Not all the hospitals had any microbiological testing for their kitchens. Ten of the hospitals kitchens had medical certificate and two not had certificate and nine of the hospitals check every six months and only one every year. All of the hospitals release food handlers when ill with fever, diarrhea or any other symptoms.

The most pathogenic bacteria were found Pseudomonas, Staphylococcus, Proteus, Klebsiella, Enterobacteria, Salmonella, Camplybacteria and Fungi. The bacteriological quality of meals, food handlers, environment, surfaces, utensils and equipment improved after training interventions.

\section{Recommendation}

The study was recommended the Ministry of Health to design kitchens with standardization. Further exploratory studies need to be taken to understand the reasons for Proteus and Enterirobacteria in kitchens for all hospitals (Governmental and private).

\section{Compliance with ethical standards}

\section{Acknowledgments}

We express our heartfelt thanks to supervisors for their devotion, guidance and prompt response to my calls for attention. A special gratitude goes to all heads of departments in hospitals kitchen for their support during data collection. 


\section{Disclosure of conflict of interest}

No disclosure of conflict of interest.

\section{Statement of informed consent}

The research approval was obtained from the university and was obtained from the Khartoum state ministry of health research department that have authorizing data collection from hospitals.

\section{References}

[1] Epub. Food Sci.Technol (Campinas) Brazil. 2013; 33: 3(2).

[2] Havelaar AH, Brul S, De Jonge A, De Jonge R, Zwietering $\mathrm{MH}$, et al. Future challenges to microbial food safety.International Journal Food Microbial. 2010; 139: 79-94.

[3] Jacxsens L, Uyttendaele M, Devlieghere F, Rovira J, Gomez SO, et al. Food safety performance indicators to benchmark food safety output of food safety management systems. International Journal Food Microbial. 2010; 141: 180-178.

[4] Nkere CK, Ibe NI, Iroegbu CU. Bacteriological quality of foods and water sold by vendors and in restaurants in Nsukka, Enugu State, Nigeria: A comparative study of three microbiological methods. Journal Health Population Nutrition. 2011; 29: 560- 566.

[5] Fletcher SM, Stark D, Ellis J. Prevalence of gastrointestinal pathogens in sub-Saharan Africa: Systematic review and Meta -analysis. Journal Public Health Africa. 2001; 2: 127-137.

[6] Food and Drug Administration Bad bug book. Foodborne pathogenic microorganisms and natural toxins handbook. Center for Food Safety and Applied Nutrition. 2012.

[7] Nguz K. Assessing food safety system in Sub-Saharan African countries: An overview of key issues. Food Control. 2007; 18: 31-134.

[8] Downes FP, Ito K. Compendium of methods for microbiological examination of foods. American Public Health Association, Washington DC, USA. 2001.

[9] Fung. Ranges of Microorganisms for Applied Microbiology, Journal of Food Protection. 1980; 43: 547-550.

[10] ICMSF. Microorganisms in Foods 1: Their Significance and Methods of Enumeration 2ndEdition, Academic Press, New York. 1978; 115-220.

[11] International Organization for Standardization. Microbiology general guidance for the preparation of dilutions for microbiological examination. Geneva: International Organization for Standardization. 1983; ISO 6887.

[12] Jackim Nyamari. Evaluation of Compliance to Food Safety Standards amongst Food Handlers in Selected Hospitals in Kenya. 2013.

[13] Monica.A.Wandolo. Food Safety and Hygiene Practices: A Comparative Study of Selected Technical and Vocational Education and Training and University Hospitality Schools in Kenya. 2016.

[14] Zienab Ahmed Yousif Omer. Hygiene and Safety of Food Prepared for Patients at Khartoum Hospitals. Sudan. 2017.

[15] L Konstansa, et al. Hygiene training of food handlers in hospital setting: important factor in the prevention of nosocomial infections. Cent Eur J Public Health. 2013; 21(3): 146-149. 